\title{
A performance e seus desdobramentos na obra de Márcia X e Cinthia Marcelle
}

\section{Caio César P. R.V. da Silva*, Sylvia H. Furegatti.}

\section{Resumo}

Este trabalho tem como objetivo estudar obras de Performance das artistas brasileiras Márcia X e Cinthia Marcelle, relacionando seus modos operativos e suas relações com os vestígios destes trabalhos (fotografias, instalações artísticas, vídeos, etc).

\section{Palavras-chave: \\ Performance artística, Márcia X, Cinthia Marcelle}

\section{Introdução}

Voltada para o campo da Performance, o objetivo desta pesquisa é estudar os vestígios da ações no trabalho "Pancake" (2001), de Márcia X e "Sobre este mesmo mundo" (2009-2010), de Cinthia Marcelle, partindo do ponto de vista que considera o vestígio como toda a gama de trabalhos criados a partir das ações performativas. Assim, foram estudadas fotografias, vídeos e instalações artísticas destes trabalhos, procurando entender a relação destas artistas com essa produção, compreendendo sua potência em gerar novos discursos e a portar seus próprios significados estéticos. "Pancake" foi uma performance apresentada pela primeira vez pela artista Márcia X em maio de 2001, na cidade do Rio de Janeiro, numa exposição de arte independente chamada "Orlândia, ocupação de uma casa em obras" realizada na casa em reforma do artista Ricardo Ventura. ${ }^{1}$ Nela, Márcia fica dentro de uma bacia de alumínio e abre 11 latas de leite condensado, cada uma pesando $2,5 \mathrm{~kg}$, utilizando um ponteiro e uma marreta. Uma a uma, ela despeja seu conteúdo na cabeça, sujando seu corpo e roupas com o doce amarelo. Em seguida, abre pacotes de confeito colorido, peneirando-os sobre o leite condensado. Os resíduos permanecem no local em instalação artística. Da ação feita na exposição também criou-se um vídeo e fotografias, registradas pelo fotógrafo Wilton Montenegro. "Sobre este mesmo mundo" (2009-2010) é uma instalação da artista Cinthia Marcelle que foi concebida em parceria dos curadores Michael Asburry e Isobell Whitelleg e do cineasta Tiago Mata Machado durante residência da artista na Camberwell College Of Arts, em Londres. ${ }^{3}$ Realizando o que a artista chama de ruína da linguagem, a obra consiste numa lousa de oito metros de comprimento. Nela, escritos são feitos e apagados, gerando pilhas de pó no chão. A obra circula com um manual de instruções, que sugere algumas inscrições e pede que outras sejam incorporadas, gerando novas montagens a cada exposição que a participa.

\section{Resultados e Discussão}

Marcelle é uma artista que investiga o gesto do outro em relação ao seu. Suas performances sempre envolvem proposições, que são retrabalhadas pela artista. Pensando no recorte proposto por esta Pesquisa, é importante destacar que esta operação é feita sobretudo através da linguagem audiovisual e das instalações artísticas, como é o caso de "Sobre este mesmo mundo". Assim, a artista não só reconhece a independência e status de obra que os vestígios podem ter, como faz disso como parte fundamental do seu método de trabalho. ${ }^{4}$ Márcia $X$ faz de seu corpo o centro das suas performances, sempre apontando para temas que tocam um coletivo, como é o caso das figuras e estereótipos da mulher, o sexo, etc. Durante a fase final de sua obra antes de sua morte prematura em 2005, realiza a série de performances em que sempre tenta desdobrar a ação em instalações artísticas, vídeos e fotografias. Como aponta Tales Frey em Discursos Críticos Através da Poética de Márcia X (2012), esta postura da artista revela sua percepção nos direcionamentos da arte contemporânea em não se fixar em um suporte, multiplicando seu conceito dentro de outras obras. "Cair em si" (2002), obra desta fase, teve seu vídeo projetado sobre cem toneladas de areia, fazendo pensar nesta atualização e desdobramento perseguidos pela artista. ${ }^{5}$

\section{Conclusão}

Dentro do campo da Performance no Brasil, é possível concluir através dos estudos desta Pesquisa que os vestígios destes trabalhos carregam um status ambíguo. Se por um lado ainda há um posicionamento ideológico ${ }^{6}$ em tratá-los como registro, sem necessariamente ter o status de obra, artistas como as pesquisadas neste trabalho já demonstram um posicionamento diferente, em que o vestígio é um trabalho que tensiona e atualiza a ação performática.

1. Descrição da per.formance. Disponível em

<http://marciax.art.br/mxObra.asp?sMenu=2\&sObra=1> Acesso em 05 de julho de 2019.

2. Créditos no site da artista. Disponúvel em

<http://marciax.art.br/mxText.asp?sMenu=6\&sText=9>. Acesso em05 de julho de 2019.

3. Entrevista realizada com Cinthia Marcelle em 21 de setembro de 2018.

4. Entrevista realizada com Cinthia Marcelle em 10 de novembro de 2018

5. FREY, Tales. Exaustão do Corpo. In: Discursos Críticos Através da Poética de Márcia X. n.p (Publicação Digital)

6. GOLDBERG, RoseLee. A arte das ideias. In: A Arte da Performance: do Futurismo ao Presente, p 193 